\title{
Alginate formation in Azotobacter vinelandii UWD during stationary phase and the turnover of poly- $\beta$-hydroxybutyrate
}

\author{
William J. Page, Anne Tindale, Mark Chandra and Elena Kwon
}

Department of Biological Sciences, University of Alberta, Edmonton, Alberta, Canada T6G 2E9
Author for correspondence: William J. Page. Tel: +1 780492 4782. Fax: +1 7804922216. e-mail : bill.page@ualberta.ca

Azotobacter vinelandii UWD is a mutant of strain UW that is defective in the respiratory oxidation of NADH. This mutation causes an overproduction of polyhydroxyalkanoates (PHAs), as polyester synthesis is used as an alternative electron sink. Since PHAs have potential for use as natural, biodegradable plastics, studies of physiology related to their production are of interest. Alginate production by this strain is limited to $<11 \mu \mathrm{g}(\mathrm{mg} \text { cell protein })^{-1}$, which permits high efficiency conversion of carbon source into PHA. However, $\geq \mathbf{4 0 0} \boldsymbol{\mu g}$ ( $\mathrm{mg}$ cell protein) $^{-1}$ was formed when UWD cells were oxygen-limited and in the stationary phase of growth. Alginate formation was fuelled by PHA turnover, which was coincident with the synthesis of alkyl resorcinols, under conditions of exogenous glucose limitation. However, alginate production was a phenotypic and reversible change. Alginate production was stopped by interruption of algD with Tn5lacz. LacZ activity in UWD was shown to increase in stationary phase, while Lacz activity in a similarly constructed mutant of strain UW did not. Transcription of algD in strain UWD started from a previously identified RpoD promoter and not from the AlgU (RpoE) promoter. This is because strain UWD has a natural insertion element in algU. Differences between strain UW and UWD may reside in the defective respiratory oxidation of NADH, where the NADH surplus in strain UWD may act as a signal of stationary phase. Indeed, a backcross of UW DNA into UWD generated NADHoxidase-proficient cells that failed to form alginate in stationary phase. Evidence is also presented to show that the RpoD promoter may be recognized by the stationary phase sigma factor (RpoS), which may mediate alginate production in strain UWD.

Keywords: Azotobacter vinelandii, alginate, algU, poly- $\beta$-hydroxybutyrate, RpoS

\section{INTRODUCTION}

Azotobacter vinelandii strain UWD has been studied intensively as a candidate for the commercial production of polyhydroxyalkanoates (PHAs), which can be used as natural, biodegradable plastics (Chen \& Page, 1997; Page, 1992; Page et al., 1992). A mutation in strain UWD limits the respiratory oxidation of NADH, which results in a constitutive PHA hyperproduction phenotype as the synthesis of poly- $\beta$-hydroxybutyrate (PHB) is used as an alternative electron sink to consume excess

Abbreviations: PHA, polyhydroxyalkanoate; PHB, poly- $\beta$-hydroxybutyrate.
NAD $(\mathrm{P}) \mathrm{H}$ during growth (Page \& Knosp, 1989; Page \& Manchak, 1994). Thus PHA production is increased by aerobic conditions, which promote rapid sugar catabolism and the rapid generation of $\mathrm{NAD}(\mathrm{P}) \mathrm{H}$ (Page, 1990).

The PHB-hyperproduction phenotype was originally created in A. vinelandii strain 113 by nitrosoguanidine mutagenesis (Page \& Knosp, 1989). However, strain 113 is unsuited to commercial PHB production because it forms copious amounts of extracellular alginate. Thus strain UWD was created by transformation of the PHBhyperproduction trait of strain 113 into A. vinelandii strain UW (Page \& Knosp, 1989), an alginate-minus host (Bush \& Wilson, 1959). The capsule-minus geno- 
type of strain UW is extremely stable and spontaneous revertants to the capsule-positive phenotype have never been reported.

However, the alginate biosynthetic pathway is intact in strain UW and very limited alginate production has been observed after prolonged incubation (Page, 1983). The A. vinelandii biosynthetic pathway has been shown previously to be identical to that found in Pseudomonas aeruginosa and many of the genes are conserved (Fialho et al., 1990; Gacesa, 1998; Rehm et al., 1996). The transcriptional activation of the GDP-mannose dehydrogenase gene $(\operatorname{alg} D)$ is a key point in pathway regulation (Campos et al., 1996) and is mediated by the alternative sigma factor AlgU, a homologue of RpoE (MartinezSalazar et al., 1996). Recently it was shown that $A$. vinelandii strain UW136 has a natural insertion element in the algU gene (Martinez-Salazar et al., 1996), which may explain the alginate-minus phenotype of strains derived from UW.

We have recently been using $\mathrm{O}_{2}$-limited culture for the production of higher yields of PHA in strain UWD (Chen \& Page, 1997). The promotion of PHA formation by $\mathrm{O}_{2}$ limitation is commonly used with other bacteria (Anderson \& Dawes, 1990) and does increase PHA yield in strain UWD. However, we have observed that the culture can become viscous, leading to foam stabilization and difficulty harvesting the cells (unpublished results). In this study, we show that strain UWD can form a significant amount of alginate in an AlgUindependent manner during the turnover of PHB.

\section{METHODS}

Bacterial cultures and growth conditions. The strains used in this study included Azotobacter vinelandii UW (ATCC 13705), its rifampin-resistant derivative UW136 (Dr P.E. Bishop, North Carolina State University, Raleigh, NC, USA), the PHB-hyperproducing strain UWD (ATCC 53799) (Page \& Knosp, 1989) and the capsule-positive strain O (ATCC 12518). A. vinelandii strain $\mathrm{U} 5$ had algD insertionally inactivated by Tn5lacZ mutagenesis of strain UW136 (Campos et al., 1996). Strain DU5 (algD:: Tn5lacZ in strain UWD) and strain DC (UWD backcrossed with UW DNA) were constructed in this study by transformation (Page \& von Tigerstrom, 1979).

The strains were routinely grown in Burk's buffer salts (Page \& Sadoff, 1976), supplemented with ferric citrate to bring the total iron concentration to $50 \mu \mathrm{M}, 2 \%$ (w/v) glucose and $15 \mathrm{mM}$ ammonium acetate (Burk's medium). The medium for optimal PHB production was Burk's buffer salts, $50 \mu \mathrm{M}$ ferric citrate, $3 \%(\mathrm{w} / \mathrm{v})$ glucose and $0 \cdot 1 \%(\mathrm{w} / \mathrm{v})$ fish peptone (Page, 1992). Cultures were incubated at high or low aeration $(50 \mathrm{ml}$ or $100 \mathrm{ml}$ per $500 \mathrm{ml}$ Erlenmeyer flask, respectively) with shaking at 225 r.p.m. at $28-30{ }^{\circ} \mathrm{C}$. Growth curves were constructed from multiple flasks that were inoculated at the same time so that all the samples at a time point were removed from a single flask. Low-aeration conditions were also created for the incubation of Petri plates using a microaerophilic gasgenerating kit (Oxoid CampyPak) in various sized jars to give a calculated 6, 11 and $16 \%(\mathrm{v} / \mathrm{v}) \mathrm{O}_{2}$.

Strain UWD cells for shift-down growth experiments were grown for $48 \mathrm{~h}$ in $100 \mathrm{ml}$ Burk's medium, then harvested by centrifugation, washed in Burk's buffer and resuspended in an equal volume of Burk's buffer. The cell suspension was dispensed $20 \mathrm{ml}$ per $50 \mathrm{ml}$ Erlenmeyer flask and incubated at $30{ }^{\circ} \mathrm{C}$ with shaking at 225 r.p.m. for up to $8 \mathrm{~d}$.

Analysis of cells and culture fluids. Capsule was solubilized by the addition of $1 \mathrm{ml} 5.0 \mathrm{M} \mathrm{NaCl}$ and $2 \mathrm{ml} 0.05 \mathrm{M}$ disodium EDTA, $\mathrm{pH} 7 \cdot 0$, to $50 \mathrm{ml}$ culture prior to centrifugation at $10000 \mathrm{~g}(10 \mathrm{~min})$ to remove the cells. Alginate in the culture supernatant fluid was precipitated with 3 vols ice-cold $95 \%$ (w/v) ethanol overnight at $4{ }^{\circ} \mathrm{C}$. The precipitated alginate was collected on a Whatman GF/A glass fibre filter and dissolved in $0.1 \mathrm{M} \mathrm{NaOH}$ at room temperature prior to assay by the carbazole assay (Knutson \& Jeanes, 1968) using commercial alginate (Sigma) as a standard. PHB dry weight was determined after digestion of cell material in commercial bleach (Law \& Slepecky, 1961). Cell protein, glucose and ammonia remaining in the culture fluid were determined by colorimetric assays [the Lowry method, Trinder - Sigma Diagnostics, and Bergersen (1980), respectively]. Alkyl resorcinols were extracted from cell material with acetone overnight at room temperature (Kozubek \& Tyman, 1995), then assayed by a colorimetric assay using Fast Blue B with orcinol as the standard (Tluscik et al., 1981). $\beta$-Galactosidase specific activity (Miller, 1972) was measured as $A_{420}(\mathrm{mg} \text { cell protein })^{-1} \mathrm{~h}^{-1}$, rather than optical density, because culture optical density was greatly affected by the PHB content of the cells. NADH oxidase activity was assayed as described previously (Page, 1991).

DNA isolation and PCR amplification of algU. Chromosomal DNA was extracted from A. vinelandii (Robson et al., 1984). The region of $\operatorname{alg} U$ expected to contain a natural insertion element (Martinez-Salazar et al., 1996) was amplified by PCR. The Expand Long Template PCR System (Boehringer Mannheim) was used in buffer system 3 with $200 \mu \mathrm{M}$ dNTPs, $1.25 \mu \mathrm{M}$ of each primer, $1.5 \mathrm{mM} \mathrm{MgCl}_{2}, 400 \mathrm{ng}$ chromosomal DNA, $5 \%(\mathrm{v} / \mathrm{v})$ DMSO and 2.5 units of the DNA polymerase mix in a final volume of $100 \mu \mathrm{l}$. The primers for algU amplification were WJP13 (5'-ATGTTAAACCAGGAGCAAGATCA-3') and WJP46 (5'-CATAAAACTCGGCATCACCTGCA-3'). The PCR program (Minicycler, MJ Research) was: 5 min denaturation at $95^{\circ} \mathrm{C}$, followed by 30 cycles of $30 \mathrm{~s}$ denaturation at $95^{\circ} \mathrm{C}, 1 \mathrm{~min}$ annealing at $37^{\circ} \mathrm{C}$, and 2 min extension at $68^{\circ} \mathrm{C}$.

Southern hybridization followed standard procedures (Southern, 1975), using ${ }^{32}$ P-end-labelled WJP12 (5'-GGCTATGTCTGAGTTAGCTGTT-3') as a probe for the insertion element and WJP51 (5'-GAAAATGCTGATACGCATTGCGTTC-3') as a probe for $\operatorname{alg} D$.

RNA extraction and primer extension analysis. A. vinelandii cultures were grown for 24 and 48 h in Burk's medium prior to RNA extraction and primer extension analysis as described previously (Tindale et al., 2000). The oligonucleotide WJP51 was used as the primer.

The sequence ladder used to identify the starts of $\operatorname{alg} D$ transcription was derived from the strain UWD algD promoter region, which had been amplified by PCR using primers WJP50 and WJP49. Primer WJP50 hybridized with a sequence 389 nt upstream of the start of the A. vinelandii ATCC 9046 algD gene (Campos et al., 1996) and had a PstI site (lower case) tagged on for subsequent cloning of the PCR product: 5'-ctctctgcagATTCACCTATTCCACACTGG-3'. The reverse primer WJP49 hybridized with a sequence 199 nt into the algD gene and had an EcoRI site (lower case) tagged on: 5'-tctcgaattcGGGGATTTGCCCTGATTGAT-3'. The amplified strain UWD algD promoter region was found to have a nucleotide sequence identical to the $\operatorname{alg} D$ promoter region of ATCC 9046 (GenBank U11240). 


\section{RESULTS AND DISCUSSION}

\section{Alginate formation by strain UWD}

Under high-aeration conditions, strains UW and UWD formed $<5 \mu$ g alginate $(\mathrm{mg} \text { cell protein })^{-1}$ during $24 \mathrm{~h}$ incubation and at most $11 \mu \mathrm{g}$ alginate $(\mathrm{mg} \text { cell protein })^{-1}$
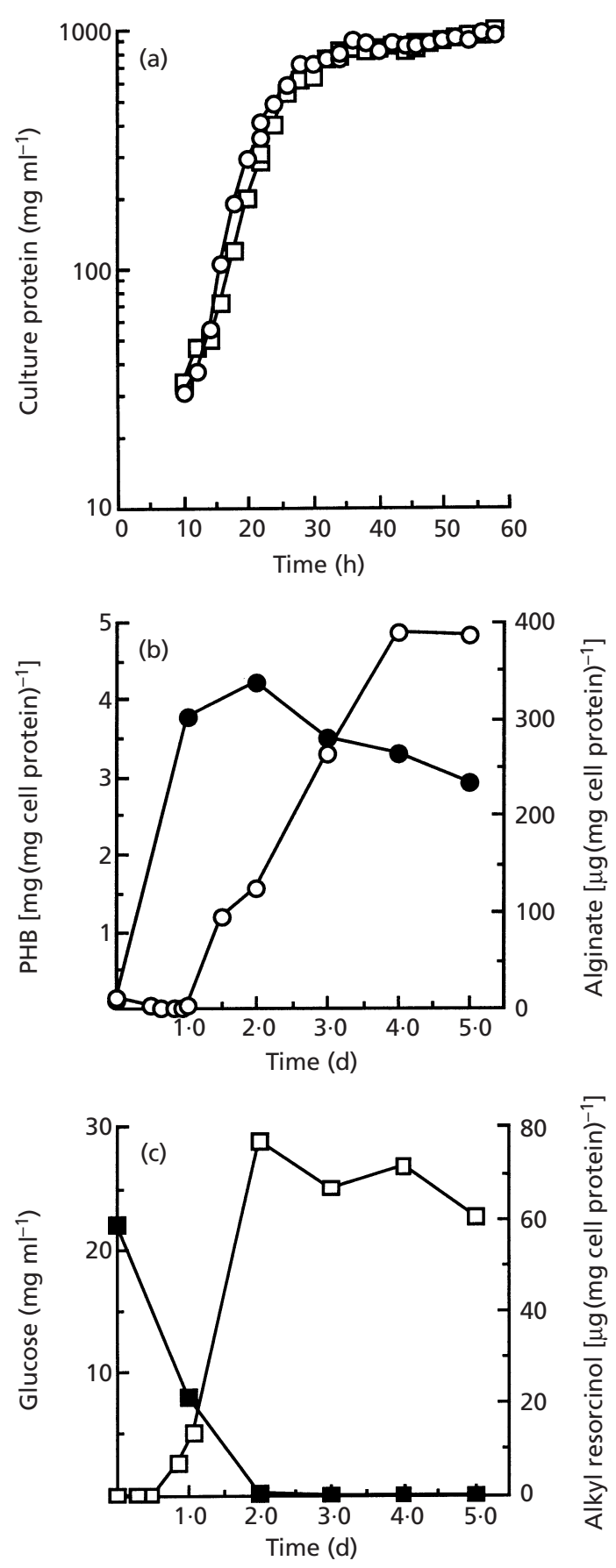

Fig. 1. Alginate production by strain UWD. Cultures were incubated under reduced aeration conditions and the biomass of strains UW (O) and UWD ( $\square$ ) (a), and PHB (O) and alginate production ( $O$ ) (b) were assayed. (c) Alkyl resorcinol production $(\square)$ coincided with glucose limitation ( $\square$ ).

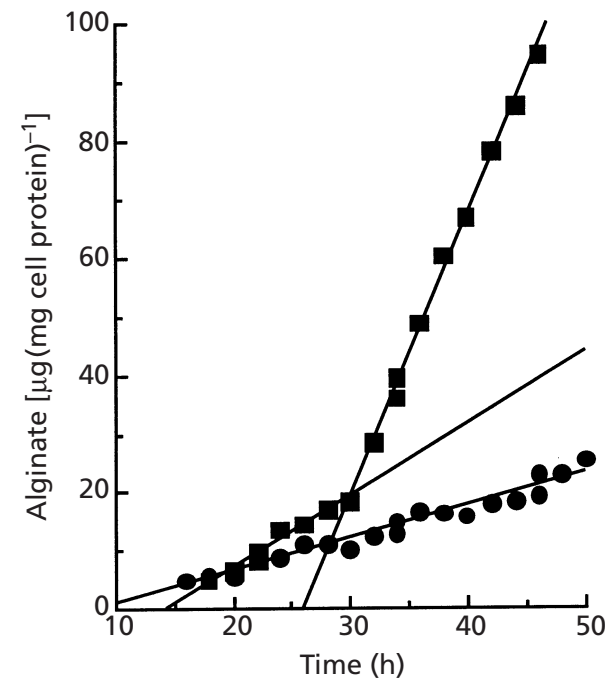

Fig. 2. Rates of alginate production in strains UWD and UW. Alginate production by strains UWD ( $\boldsymbol{\square}$ ) and UW (0) was measured in cultures grown at reduced aeration. Best fit lines using mean values are shown. Duplicate cultures differed by $\pm 5 \mu \mathrm{g}$ (mg cell protein) ${ }^{-1}$.

after $48 \mathrm{~h}$ incubation. By comparison, alginate formed by the capsule-positive, parent strain $\mathrm{O}$ was about $400 \mu \mathrm{g}$ (mg cell protein $)^{-1}$ after $24 \mathrm{~h}$ and at least $1 \mathrm{mg}$ $(\mathrm{mg} \text { cell protein })^{-1}$ after $48 \mathrm{~h}$. However, significant amounts of alginate were formed by strain UWD under reduced aeration conditions. Increased alginate production was first observed at about $36 \mathrm{~h}$ at the onset of the stationary phase of growth and it continued for $4 \mathrm{~d}$, yielding about $400 \mu \mathrm{g}$ alginate $\left(\mathrm{mg}\right.$ cell protein) ${ }^{-1}$ (Fig. $1 \mathrm{a}, \mathrm{b})$. The culture was ammonium-limited by $20 \mathrm{~h}$ (data not shown) and glucose-limited by $2 \mathrm{~d}$ (Fig. 1b). Thus a large amount of alginate was formed after glucose limitation.

The most likely source of carbon for continued alginate formation by strain UWD was PHB, which appeared to be turned over after $2 \mathrm{~d}$ (Fig. 1b). PHB was turned over at a rate of $400 \mu \mathrm{g}(\mathrm{mg} \text { cell protein })^{-1} \mathrm{~d}^{-1}\left(r^{2}=0.945\right)$ and the alginate production rate was $90 \mu \mathrm{g}$ (mg cell protein $)^{-1} \mathrm{~d}^{-1}\left(r^{2}=0.926\right)$. Turnover of PHB was also indicated by the production of alkyl resorcinols, which are specifically formed by PHB catabolism (Reusch \& Sadoff, 1981). Elevated levels of resorcinols coincided with exogenous glucose exhaustion (Fig. 1c) and increased alginate formation (Fig. 1b).

When alginate production by strain UWD was examined on a finer timescale, two rates of alginate formation occurred during the first $50 \mathrm{~h}$ of incubation (Fig. 2). During exponential growth (at times prior to $30 \mathrm{~h}$, Fig. 1a), the alginate production rate was $1 \cdot 2 \mu \mathrm{g}(\mathrm{mg}$ cell protein $)^{-1} \mathrm{~h}^{-1}\left(r^{2}=0.969\right)$. During stationary phase, the rate increased to $4.8 \mu \mathrm{g}$ (mg cell protein $)^{-1} \mathrm{~h}^{-1}\left(r^{2}=\right.$ $0 \cdot 997)$. This rate was similar in magnitude to the longterm rate of $3.8 \mu \mathrm{g}(\mathrm{mg} \text { cell protein })^{-1} \mathrm{~h}^{-1}$ observed in 

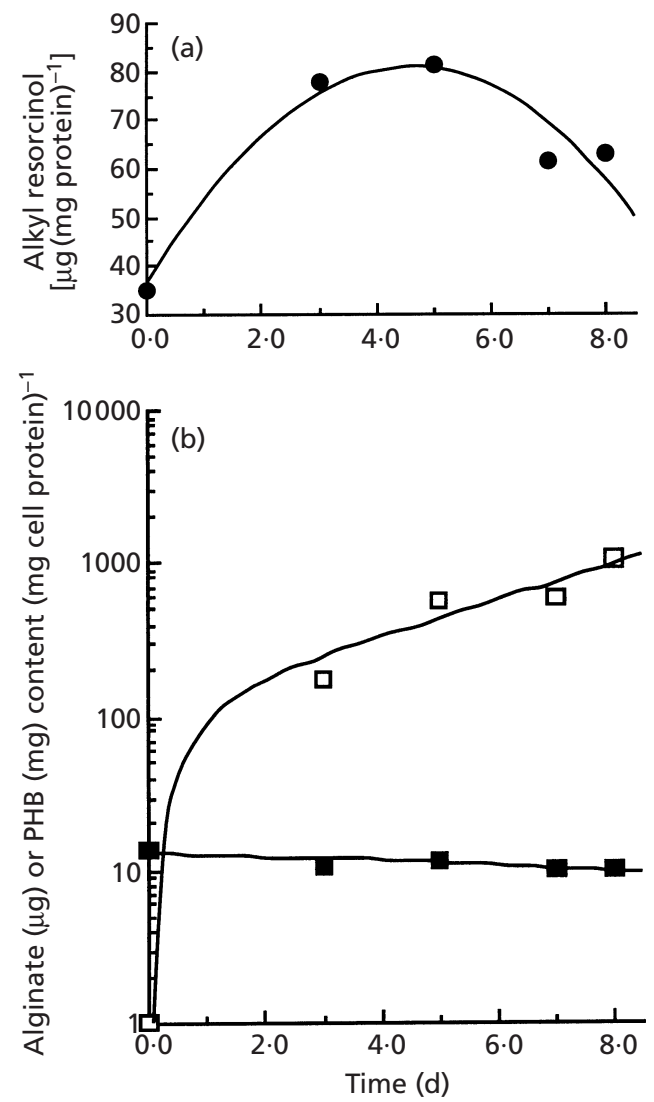

Fig. 3. Alginate production by PHB-filled strain UWD cells. Cells, grown for $48 \mathrm{~h}$ in glucose medium, were harvested, washed and resuspended in Burk's buffer (without exogenous carbon source). (a) Alkyl resorcinol (๑) and (b) alginate ( $\square$ ) and PHB (ם) content of the cells was measured during $8 \mathrm{~d}$ further incubation.

Fig. 1(b). In contrast, strain UW formed alginate at a low but constant rate of $0.6 \mu \mathrm{g}(\mathrm{mg} \text { cell protein })^{-1} \mathrm{~h}^{-1}\left(r^{2}\right.$ $=0.951$ ) (Fig. 2). Strain $\mathrm{O}$ formed alginate at a much higher rate of $168 \mu \mathrm{g}(\mathrm{mg} \text { cell protein })^{-1} \mathrm{~h}^{-1}\left(r^{2}=0 \cdot 887\right)$ until stationary phase, when the rate decreased to $\approx 3 \mu \mathrm{g}$ (mg cell protein) ${ }^{-1} \mathrm{~h}^{-1}\left(r^{2}=0 \cdot 031\right)$, presumably due to $\mathrm{O}_{2}$ limitation (data not shown).

The alginate formed by strain UWD was loosely associated with the cell and was released into the culture fluid. Centrifugation of these cultures (without prior $\mathrm{NaCl}$ and EDTA treatment) gave soft mucoid cell pellets characteristic of strain O. However, when strain UWD was sampled from a $48 \mathrm{~h}$ culture and streaked onto solid medium, the isolated colonies that formed were not mucoid like strain $\mathrm{O}$, but had the typical butyrous morphology of strain UW, with the opaque white colour characteristic of strain UWD (Page \& Knosp, 1989). Strain UWD also failed to form mucoid colonies when the plates were incubated for 1 week under reduced $\mathrm{O}_{2}$ concentrations. Thus the production of alginate by strain UWD was not due to reversion to a capsulepositive genotype, but appeared to be a reversible, phenotypic change.

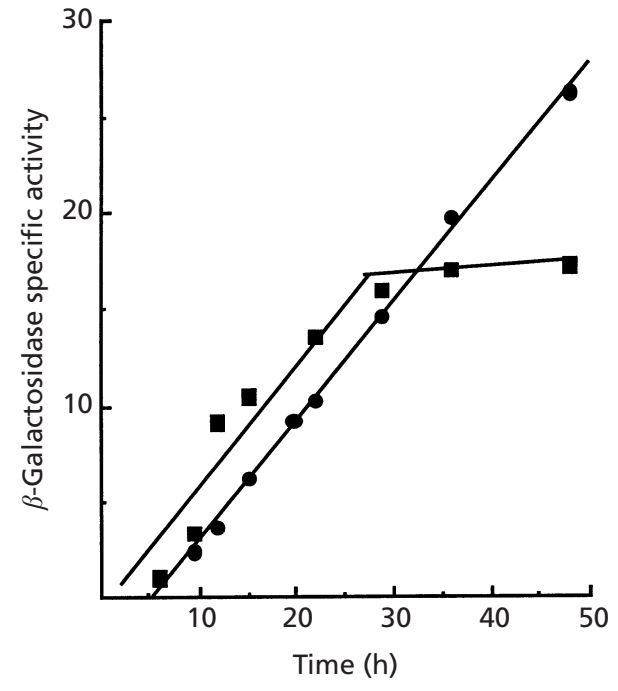

Fig. 4. Transcriptional activity of algD::lacz fusion in strains DU5 and U5. $\beta$-Galactosidase activity in strains DU5 (O) and U5 (ם) during incubation at reduced aeration is shown. Stationary phase occurred at about $30 \mathrm{~h}$, as in Fig. 1(a). Best fit lines using mean values (duplicate cultures differed by \pm 2.5 specific activity units) are shown.

\section{PHB-filled cells form alginate}

In order to confirm that alginate formed by strain UWD was derived from PHB turnover, cells that had been grown for $48 \mathrm{~h}$ in Burk's medium were used to inoculate Burk's buffer (without an exogenous carbon source) and incubated for up to $8 \mathrm{~d}$. During the course of this nutrient shift-down, extracellular alginate rapidly increased while PHB decreased from 13.4 to $9.8 \mathrm{mg}$ (mg cell protein $)^{-1}$ (Fig. 3b). Alkyl resorcinols also formed coincident with PHB turnover in the first $5 \mathrm{~d}$ of incubation (Fig. 3a). The rate of PHB degradation was $407 \mu \mathrm{g}(\mathrm{mg} \text { cell protein })^{-1} \mathrm{~d}^{-1}\left(r^{2}=0.740\right)$ and the rate of alginate formation was $147 \mu \mathrm{g}$ (mg cell protein $)^{-1} \mathrm{~d}^{-1}$ $\left(r^{2}=0 \cdot 854\right)$.

PHB turnover will result in the formation of acetyl-CoA (Anderson \& Dawes, 1990), with gluconeogenesis forming glyceraldehyde 3-phosphate at the branch point from the Entner-Doudoroff pathway to alginate production (Beale \& Foster, 1996). On a carbon basis alone, $1.5 \mathrm{~mol} \beta$-hydroxybutyrate $\left(\mathrm{C}_{4}\right)$ would need to be consumed to generate $1 \mathrm{~mol}$ mannuronic acid $\left(\mathrm{C}_{6}\right)$. Since the residual cell mass (cell dry weight minus PHB dry weight) did not change significantly during stationary phase (data not shown), the amount of PHB turned over in Figs 1 and 3 is more than sufficient to account for the alginate formation observed.

\section{Inactivation of alginate formation in strain UWD}

DNA from A. vinelandii strain U5 (algD:: Tn5lacZ) was transformed into strain UWD and $\mathrm{Kan}^{\mathrm{R}}$ transformants were selected. These transformants (designated DU5) formed $\leqslant 5 \mu$ g alginate $(\mathrm{mg} \text { cell protein })^{-1}$ under $\mathrm{O}_{2}{ }^{-}$ 
(a)

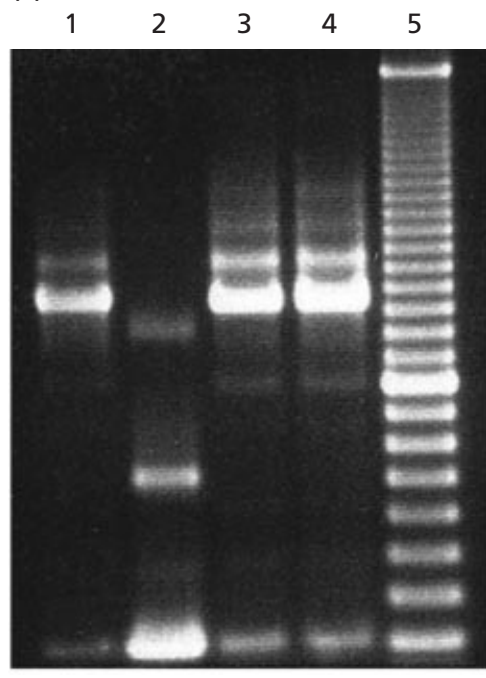

(b)

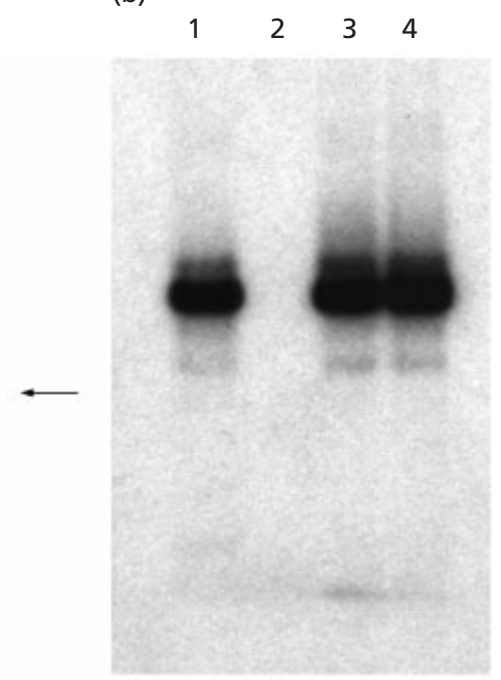

Fig. 5. Identification of the insertion element in the algU gene. (a) PCR was conducted using primers WJP13 and WJP46 and chromosomal DNA as the template. Products obtained with strains UWD (lane 1), O (lane 2), UW136 (lane 3), UW (lane 4) and $100 \mathrm{bp}$ molecular mass standard (lane 5) were resolved on a $1.2 \%$ agarose gel. (b) Southern blot of gel (a) probed with the end-labelled insertion element probe. Arrow indicates $1000 \mathrm{bp}$ standard. limited growth conditions, suggesting that homologous recombination and inactivation of algD had occurred. This was confirmed by Southern hybridization of NotIdigested chromosomal DNA using WJP51 as a probe for $\operatorname{algD}$. Strains UWD, U5 and DU5 produced a single restriction fragment that contained algD. The U5 and DU5 fragment was larger than that found in UWD, owing to the insertion of about $4 \mathrm{~kb}$ of Tn5lacZ DNA (de Lorenzo et al., 1990) into algD (data not shown).

Under optimal PHB production conditions, strain DU5 produced $8 \cdot 0 \pm 0 \cdot 2 \mathrm{mg}$ PHB (mg cell protein) ${ }^{-1}$ like strain UWD, which was four times that formed in strain UW. Strains DU5 and UWD formed PHB from glucose at maximum theoretical efficiency $\left(0.33 \pm 0.3 \mathrm{~g} \mathrm{~g}^{-1}\right)$ (Collins, 1987) since alginate formation occurred after PHB accumulation (as in Fig. 1b). Upon glucose limitation, strain DU5 turned-over PHB and formed alkyl resorcinols, but as noted above alginate was not formed.

Transcription of $\operatorname{algD}$ was examined in strains U5 and DU5 to determine if there was an obvious increase in $\operatorname{alg} D$ transcription at the times when alginate formation was active (Fig. 4). The rates of algD transcriptional activity were not significantly different in strains DU5 and U5 during the exponential phase of growth. This activity reached a plateau in strain U5 as the cells entered the stationary phase, but continued unabated in strain DU5 (Fig. 4). The amount of LacZ activity in these cells was very low, suggesting that $\operatorname{alg} D$ transcription was initiated from a weak promoter.

\section{Strain UWD has an inactive algU}

Since strain UWD was constructed by transformation with DNA from the alginate-positive strain 113, we questioned whether $\operatorname{alg} U$ was still inactive in strain UWD. The region of the $\operatorname{alg} U$ gene expected to contain the natural insertion element was amplified by PCR, using primers WJP13 (hybridizing to the $5^{\prime}$ end of $\operatorname{alg} U$ ) and WJP46 (hybridizing to algU downstream of the insertion element). The expected PCR products with and without the insertion element were about 1322 and $322 \mathrm{bp}$, respectively (calculated from Martinez-Salazar et al., 1996). As shown in Fig. 5(a), there was a prominent PCR product formed in strains UWD, UW136 and UW that was just greater than $1300 \mathrm{bp}$ and a much smaller PCR product was formed in strain $\mathrm{O}$ at $\sim 300 \mathrm{bp}$. Only the larger PCR product hybridized with oligonucleotide WJP12 (Fig. 5b), which was complementary to the insertion element sequence. Thus strain UWD had an inactive $\operatorname{alg} U$ gene as observed in strains UW and UW136.

\section{Transcription of algD in strain UWD}

Primer extension was used to determine the start of $\operatorname{alg} D$ transcription in strains $\mathrm{O}$ and UWD after 24 and $48 \mathrm{~h}$ incubation. In strain $\mathrm{O}$, transcription of $\operatorname{alg} D$ was initiated at a G (P2 in Fig. 6a, b) downstream from the AlgU promoter. This differs from that reported by Campos et al. (1996), who show the start site as the next C upstream, but their published figures are of poor quality. Transcription from P2 was not active in strain UWD (Fig. 6b), consistent with the absence of a functional algU gene (Fig. 5) and suggesting that an alternative RpoE sigma factor is not available in strain UWD to activate transcription from this promoter.

The other known start of transcription (Campos et al., 1996), designated P1, was active in both strains $\mathrm{O}$ and UWD (Fig. 6a, c). Although primer extension is not strictly quantitative, there did appear to be an increase in the use of the P1 start site in strain UWD at $48 \mathrm{~h}$, while there was no increase in the use of any of the start sites in strain $\mathrm{O}$ at $48 \mathrm{~h}$. A third site of unknown function (Campos et al., 1996) and designated P3 (Fig. 6a) was evident in strains $\mathrm{O}$ and UWD at both times (data not shown). Further description of this site, which is not likely to be a true transcription start site, will appear elsewhere (unpublished data). 
(a)

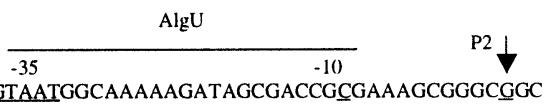

CTACAATGAATTGGATGCTGTAATGGCAAAAAGATAGCGACCGCGAAAGCGGGCGGC

CCATGACGAACCGAACATGGATCGCTTGAGCAGTTATAAAGCATCCCTTGCAACCTGC

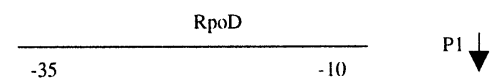

CTTTTAACGCCAGCTCAITTGGCACGACATTTTATTGACTATAATTCGGCCTGCAAATT

TCCCTTGAAGCGCGCCGGCAATGTGACGACCAAGGGTTTTAGTCGTCGACTTTTCGTTA

TAAG

(b)

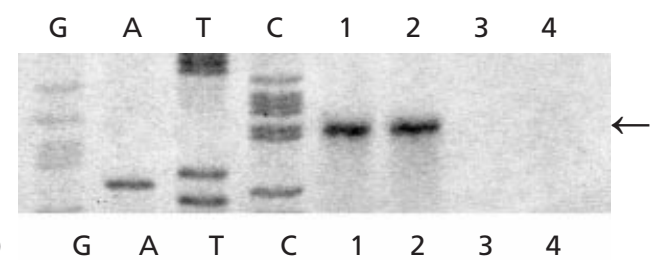

(c)

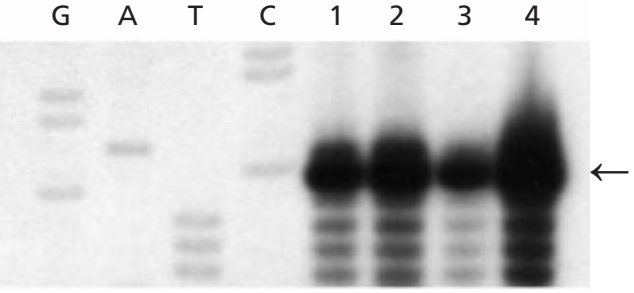

Fig. 6. Primer extension analysis of algD transcription in strains $O$ and UWD. (a) Sequence of the $\operatorname{alg} D$ upstream region, including the AlgU promoter and P2 transcription start site, RpoD promoter and P1 transcription start site, the P3 site, ribosome-binding site (rbs) and translation start site (ATG). RNA was prepared from strain $\mathrm{O}$ after $24 \mathrm{~h}$ (lane 1 ) and $48 \mathrm{~h}$ (lane 2) and UWD after $24 \mathrm{~h}$ (lane 3 ) and $48 \mathrm{~h}$ (lane 4) incubation under low-aeration incubation conditions. Starts of transcription are shown by arrows at P2 (b) and P1 (c). The sequence ladder was generated by reverse transcription from primer WJP51.

Table 1. Characteristics of strains UW, UWD and DC

Analysed after $48 \mathrm{~h}$ incubation under low-aeration conditions, using at least duplicate assays. Values are means \pm range.

\begin{tabular}{|lcccc|}
\hline Strain & $\begin{array}{c}\text { NADH oxidase } \\
\text { specific activity }\end{array}$ & $\begin{array}{c}\text { PHB } \\
{\left[\mathbf{m g}(\mathbf{m g} \text { cell protein })^{-1}\right]}\end{array}$ & $\begin{array}{c}\text { Alkyl resorcinol } \\
{\left[\boldsymbol{\mu g}(\mathbf{m g} \text { cell protein })^{-1}\right]}\end{array}$ & $\begin{array}{c}\text { Alginate } \\
{\left[\boldsymbol{\mu g}(\mathbf{m g} \text { cell protein })^{-1}\right]}\end{array}$ \\
\hline UW & $0 \cdot 71 \pm 0 \cdot 15$ & $1 \cdot 53 \pm 0.5$ & $0 \cdot 0 \pm 0 \cdot 0$ & $3 \cdot 4 \pm 3 \cdot 0$ \\
UWD & $0 \cdot 16 \pm 0 \cdot 05$ & $3 \cdot 81 \pm 0 \cdot 5$ & $63 \cdot 0 \pm 3 \cdot 0$ & $320 \cdot 0 \pm 10 \cdot 8$ \\
DC† & $0 \cdot 68 \pm 0 \cdot 10$ & $1 \cdot 87 \pm 0 \cdot 5$ & $0 \cdot 2 \pm 0 \cdot 5$ & $3 \cdot 7 \pm 1 \cdot 7$ \\
\hline
\end{tabular}

$* \mu$ mol NADH oxidized $\min ^{-1}$ (mg membrane protein $)^{-1}$.

† Mean values from analysis of 10 individual transformants.

\section{Growth-phase-dependent alginate formation}

Since strains UW and UWD are identical in terms of having an inactive $\operatorname{alg} U$, the difference in alginate formation may be a consequence of the inactive respiratory NADH oxidase in strain UWD (Page \& Knosp, 1989). To test this, strain UWD was backcrossed with strain UW DNA and less opaque (clear) colonies were picked. These colonies were not observed in strain UWD culture, but occurred at a frequency of $3 \times 10^{-2}$ in transformed culture. Ten transformants (designated DC) were analysed and found to have increased NADH oxidase activity compared to strain UWD, lower PHB yields and had minimal alginate production like strain UW (Table 1). However, strain DC was rifampicin- resistant like strain UWD, which distinguished the transformants from the donor strain UW, which was rifampicin-sensitive (Page \& Knosp, 1989).

Normally PHB is formed in the stationary phase of growth, when the culture is $\mathrm{O}_{2}$-limited or deprived of an essential nutrient other than the carbon source (Anderson \& Dawes, 1990). The abundance of NADH at the transition to stationary phase is a trigger for PHB formation (Anderson \& Dawes, 1990). Also, the $\mathrm{NADH} / \mathrm{NAD}$ ratio is a well-known regulator of catabolism (Neidhardt et al., 1990) and the redox state of a cell is a powerful regulator of gene expression (Bauer et al., 1999). The hyperproduction of alginate in strain UWD in stationary phase (Figs 1 and 2) is probably a 
reflection of increased availability of PHB for turnover. However, the increased activity of algD transcription (Fig. 4) probably also reflects altered promoter activity, rather than substrate availability per se. The RpoD promoter (P1) of algD must be important in this process, as it is the only recognized promoter that is active in strain UWD. It is possible that the RpoD promoter is also regulated by the stationary phase sigma factor RpoS, which is highly homologous to RpoD and frequently shares the same promoters (Espinosa-Urgel et al., 1996; Hengge-Aronis, 1996). Promoters with a -10 sequence similar to CTATACT and with intrinsic upstream DNA curvature would be preferentially recognized by RpoS (Espinosa-Urgel \& Tormo, 1993; Espinosa-Urgel et al., 1996). The algD P1 promoter has the -10 sequence CTATAAT (Fig. 6a) and calculations made with DNASTAR software, as described by Espinosa-Urgel \& Tormo (1993), show that the sequence upstream of P1 has intrinsic DNA curvature (data not shown). In support of this hypothesis, it has been shown that $\operatorname{alg} D$ transcription and alginate formation in A. vinelandii is regulated by GacSA, a sensor kinase that influences RpoS levels in the cell (Castaneda et al., 2000). Similarly, alginate formation in P. aeruginosa is greatly reduced in an RpoS mutant (Suh et al., 1999). Our current research will determine the role of RpoS in PHB turnover and alginate biosynthesis in $A$. vinelandii UWD.

\section{NOTE ADDED IN PROOF}

The complete sequence of the A. vinelandii UW insertion element in alg $U$ has been deposited as GenBank accession number AF322366 (D. Meakins, A. Tindale \& W. J. Page, Nov. 19, 2000).

\section{ACKNOWLEDGEMENTS}

This research was supported by a grant to W.J.P. from the Natural Sciences and Engineering Research Council (NSERC) of Canada. E. K. was also supported by summer studentships from the Alberta Heritage Foundation for Medical Research and NSERC. We thank Andrea Macyk and Diana Meakins (both supported by NSERC summer studentships), Claire Galibois, Brenda Lim-Fong, Christa Sluggett and Michelle Rooker for technical assistance with parts of this study.

\section{REFERENCES}

Anderson, A. \& Dawes, E. (1990). Occurrence, metabolism, metabolic role, and industrial uses of bacterial polyhydroxyalkanoates. Microbiol Rev 54, 450-472.

Bauer, C. E., Elsen, S. \& Bird, T. H. (1999). Mechanisms for redox control of gene expression. Annu Rev Microbiol 53, 495-523.

Beale, J. M., Jr \& Foster, J. L. (1996). Carbohydrate fluxes into alginate biosynthesis in Azotobacter vinelandii NCIB 8789: NMR investigations of the triose pools. Biochemistry 35, 4492-4501.

Bergersen, F. (1980). Measurement of nitrogen fixation by direct means. In Methods for Evaluating Biological Nitrogen Fixation, pp. 65-110. Edited by F. Bergersen. New York: Wiley.

Bush, J. \& Wilson, P. (1959). A non-gummy chromogenic strain of Azotobacter vinelandii. Nature 184, 381.
Campos, M., Martinez-Salazar, J. M., Lloret, L., Moreno, S., Nunez, C., Espin, G. \& Soberon-Chavez, G. (1996). Characterization of the gene coding for GDP-mannose dehydrogenase (algD) from Azotobacter vinelandii. J Bacteriol 178, 1793-1799.

Castaneda, M., Guzman, J., Moreno, S. \& Espin, G. (2000). The GacS sensor kinase regulates alginate and poly- $\beta$-hydroxybutyrate production in Azotobacter vinelandii. J Bacteriol 182, 2624-2628.

Chen, G.-Q. \& Page, W. J. (1997). Production of poly- $\beta$-hydroxybutyrate by Azotobacter vinelandii in a two-stage fermentation process. Biotechnol Tech 11, 347-350.

Collins, S. (1987). Choice of substrate in polyhydroxybutyrate synthesis. In Carbon Substrates in Biotechnology (Special Publication of the Society for General Microbiology no. 21), pp. 161-168. Edited by J. D. Stowell, A. J. Beardsmore, C. W. Keevil $\&$ J. R. Woodward. Oxford: IRL Press.

Espinosa-Urgel, M. \& Tormo, A. (1993). $\sigma^{\mathrm{s}}$-dependent promoters in Escherichia coli are located in DNA regions with intrinsic curvature. Nucleic Acids Res 21, 3667-3670.

Espinosa-Urgel, M., Chamizo, C. \& Tormo, A. (1996). A consensus structure for $\sigma^{\mathrm{s}}$-dependent promoters. Mol Microbiol 21, 657-659.

Fialho, A. M., Zielinski, N. A., Fett, W. F., Chakrabarty, A. M. \& Berry, A. (1990). Distribution of alginate gene sequences in the Pseudomonas rRNA homology group I-Azomonas-Azotobacter lineage of superfamily B procaryotes. Appl Environ Microbiol 56, 436-443.

Gacesa, P. (1998). Bacterial alginate biosynthesis - recent progress and future prospects. Microbiology 144, 1133-1143.

Hengge-Aronis, R. (1996). Back to log phase: sigma $S$ as a global regulator in the osmotic control of gene expression in Escherichia coli. Mol Microbiol 21, 887-893.

Knutson, C. \& Jeanes, A. (1968). A new modification of the carbazole analysis: application to heteropolysaccharides. Anal Biochem 24, 470-481.

Kozubek, A. \& Tyman, J. (1995). Cereal grain resorcinolic lipids: mono and dienoic homologues are present in rye grains. Chem Phys Lipids 78, 29-35.

Law, J. \& Slepecky, R. (1961). Assay of poly- $\beta$-hydroxybutyric acid. J Bacteriol 82, 33-36.

de Lorenzo, V., Herrero, M., Jakubzik, U. \& Timmis, K. N. (1990). Mini-Tn5 transposon derivatives for insertional mutagenesis, promoter probing, and chromosomal insertion of cloned DNA in Gram-negative eubacteria. J Bacteriol 172, 6568-6572.

Martinez-Salazar, J. M., Moreno, S., Najera, R., Boucher, J. C., Espin, G., Soberon-Chavez, G. \& Deretic, V. (1996). Characterization of the genes coding for the putative sigma factor $\mathrm{Alg} U$ and its regulators MucA, MucB, MucC, and MucD in Azotobacter vinelandii and evaluation of their roles in alginate biosynthesis. $J$ Bacteriol 178, 1800-1808.

Miller, J. (1972). Experiments in Molecular Genetics. Cold Spring Harbor, NY : Cold Spring Harbor Laboratory.

Neidhardt, F., Ingraham, J. \& Schaechter, M. (1990). Physiology of the Bacterial Cell. A Molecular Approach. Sunderland, MA: Sinauer Associates.

Page, W. J. (1983). Formation of cystlike structures by ironlimited Azotobacter vinelandii strain UW during prolonged storage. Can J Microbiol 29, 1110-1118.

Page, W. J. (1990). Production of poly- $\beta$-hydroxybutyrate by Azotobacter vinelandii UWD in beet molasses culture at high aeration. In Novel Biodegradable Microbial Polymers, pp. 423-424. Edited by E. Dawes. Dordrecht: Kluwer Academic. 
Page, W. J. (1991). Examination of the role of $\mathrm{Na}^{+}$in the physiology of the $\mathrm{Na}^{+}$-dependent soil bacterium Azotobacter salinestris. J Gen Microbiol 137, 2891-2899.

Page, W. J. (1992). Production of polyhydroxyalkanoates by Azotobacter vinelandii UWD in beet molasses culture. FEMS Microbiol Rev 103, 149-158.

Page, W. J. \& Knosp, O. (1989). Hyperproduction of poly- $\beta$ hydroxybutyrate during exponential growth of Azotobacter vinelandii UWD. Appl Environ Microbiol 55, 1335-1339.

Page, W. J. \& Manchak, J. (1994). Control of polyhydroxyalkanoate synthesis in Azotobacter vinelandii strain UWD. Microbiology 140, 953-963.

Page, W. J. \& Sadoff, H. L. (1976). Physiological factors affecting transformation of Azotobacter vinelandii. J Bacteriol 125, 1080-1087.

Page, W. J. \& von Tigerstrom, M. (1979). Optimal conditions for transformation of Azotobacter vinelandii. J Bacteriol 139, 1058-1061.

Page, W. J., Manchak, J. \& Rudy, B. (1992). Formation of poly(hydroxybutyrate-co-hydroxyvalerate) by Azotobacter vinelandii UWD. Appl Environ Microbiol 58, 2866-2873.

Rehm, B. H., Ertesvag, H. \& Valla, S. (1996). A new Azotobacter vinelandii mannuronan C-5-epimerase gene $(\operatorname{alg} G)$ is part of an alg gene cluster physically organized in a manner similar to that in Pseudomonas aeruginosa. J Bacteriol 178, 5884-5889.
Reusch, R. N. \& Sadoff, H. L. (1981). Lipid metabolism during encystment of Azotobacter vinelandii. J Bacteriol 145, 889-895.

Robson, R., Chesshyre, J., Wheeler, C., Jones, R., Woodley, P. \& Postgate, J. (1984). Genome size and complexity in Azotobacter chroococcum. J Gen Microbiol 130, 1603-1612.

Southern, E. (1975). Detection of specific sequences among DNA fragments separated by gel electrophoresis. J Mol Biol 98, 503-517.

Suh, S. J., Silo-Suh, L., Woods, D. E., Hassett, D. J., West, S. E. \& Ohman, D. E. (1999). Effect of rpoS mutation on the stress response and expression of virulence factors in Pseudomonas aeruginosa. J Bacteriol 181, 3890-3897.

Tindale, A. E., Mehrotra, M., Ottem, D. \& Page, W. J. (2000). Dual regulation of catecholate siderophore biosynthesis in Azotobacter vinelandii by iron and oxidative stress. Microbiology 146, 1617-1626.

Tluscik, F., Kozubek, A. \& Mejbaum-Katzenellenbogen, W. (1981). Alkylresorcinols in rye (secale cereale L.) grains. VI. Colorimetric micromethod for determination of alkylresorcinols with the use of diazonium salt, Fast Blue B. Acta Soc Bot Polon 50, 645-651.

Received 10 March 2000; revised 9 October 2000; accepted 10 October 2000. 